Kovaleva, A. I. (2008) Krizis identichnosti. In: Sociologiya molodezhi. Enciklopedicheskij slovar' / ed. by Yu. A. Zubok and V. I. Chuprov. Moscow, Academia. 606 p. P. 145. (In Russ.).

Krylov, A. N. (2004) Korporativnaya identichnost' dlya menedzherov $i$ marketologov : ucheb. posobie. Moscow, NIB Publ. 222 p. (In Russ.).

Perinskaya, N. A. (2008) Socializaciya professional'naya. In: Sociologiya molodezhi. Enciklopedicheskij slovar' / ed. by Yu. A. Zubok and V. I. Chuprov. Moscow, Academia. 606 p. P. 447. (In Russ.).

Submission date: 12.03 .2018$.

Перинская Наталья Алексеевна - кандидат социологических наук, доцент кафедры социологии Московского гуманитарного университета. Адрес: 111395, Россия, г. Москва, ул. Юности, А. 5, корп. 1. Тел.: +7 (499) 374-60-21. Эл. адрес: socio-mosgu@ mail.ru

Perinskaya Nataliya Alekseyevna, Candidate of Sociology, Associate Professor, Depart-ment of Sociology, MoscowUniversity for the Humanities. Postal address: 5, Bldg. 1, Yunosti St., Moscow, Russian Federation, 111395. Tel.: +7 (499) 374-60-21. E-mail: socio-mos-gu@mail.ru

DOI: $10.17805 /$ zpu.2018.2.20

\title{
Статусно-ролевая идентичность
}

\author{
А. И. КОВАЛЕВА \\ МОСКОВСКИЙ ГУМАНИТАРНЫЙ УНИВЕРСИТЕТ
}

В данной статье рассматривается термин «статусно-ролевая идентичность», обозначающий такую разновидность социальной идентичности, которая характеризует результаты процесса социальной идентификации индивида в отношении освоенных им статусов и ролей. Ключевые слова: статусно-ролевая идентичность; идентификация; социальный статус; социальная роль; молодежь

Статусно-ролевая идентичность - осознание человеком своего социального положения в обществе, принадлежности к тому или иному социальному слою. Это субъективное состояние индивида и его объективно наблюдаемое качество соответствия определенной совокупности статусов и множеству социальных ролей. Аичностная интеграция социальных статусов и ролей неповторимо индивидуальна. Такая идентичность имеет определенную устойчивость, протяженность во времени и в пространстве. Человек сохраняет свои статусы и выполняет соответствующие им социальные роли на определенном временно́м этапе, а также в условиях различных пространственных и ситуационных изменений. Общество создает социальные статусы и социальные роли, обеспечивает социальные механизмы идентификации членов общества по различным позициям. Статусно-ролевую идентичность обеспечивает система представлений о себе, конструируемая индивидом в процессе деятельности и общения, обнаруживающая себя в самооценках, чувстве самоуважения и уровне притязаний человека.

Статусно-ролевая идентичность является множественной идентичностью и отражает результаты самоидентификации индивида со многими социальными объектами, тождественность его личности по статусным и ролевым характеристикам многим другим людям, социальным слоям и социальным группам. Эта идентичность содержит статусные и соответствующие им ролевые компоненты. 
Статусная идентичность отражает формализованные и неформализованные статусы. Формализованные (формальные) статусы возникают в рамках формальных институтов и групп (статус министра, директора, бригадира, профессора, магистра и т. д.). Неформализованные (неформальные) статусы (статус лидера компании друзей, неформального лидера коллектива, уважаемого человека и т. А.) основаны на общественном мнении, а не на законах. Статусная идентичность индивида зависит от предписанности или приобретенности его статуса. Предписанный статус, как правило, человек имеет от рождения - раса, пол, родственное положение, возрастные характеристики и т. д. Индивид вынужден принимать такой статус и соответствующую ему идентичность, а если по-другому, то его идентификация уходит в отклонение, которое в каждом конкретном случае будет особо трактоваться социальным окружением и иметь те или иные последствия для судьбы конкретного человека.

Статусная идентичность, основанная на приобретаемых статусах (статус профессора, предпринимателя, жены, пианиста, офицера, студента и т. А.), - это достигнутая идентичность. Аля ее обретения необходимо приложить значительные усилия, затратить много времени для построения, апробации и присвоения индивидом. Она представляет собой наиболее высокий уровень социальной идентичности, достигаемой индивидом, когда человек знает, кто он и чего он хочет. Аостигнутой идентичностью (Marcia, 1980) обладает человек, прошедший период кризиса и самоисследований и сформировавший определенную совокупность личностно значимых для него целей, ценностей и убеждений. Таким людям присущи чувство направленности и осмысленности жизни, доверие и оптимизм в отношении будущего.

Статусная идентичность связана прежде всего с главным статусом человека, который в иерархии социальных статусов стоит на первом месте, определяет и, что очень важно, самоопределяет человека социально. Безусловно, особое значение имеет статус человека, связанный с его работой, профессией, имущественным положением. Статусная позиция гражданина представляет собой совокупность прав и обязанностей, определенных законодательными актами, а также устойчивых форм гражданского поведения, социальных ожиданий.

Однако в условиях неформальных определяющее значение могут иметь другие признаки (культурный уровень, обаяние, общительность). Аичный статус - это положение, которое человек занимает в первичной группе в зависимости от того, как он оценивается данной группой в качестве человеческого существа со своими личностными качествами. Поэтому статусная идентичность может обретать неформальное содержание и в определенной мере преобладать в имидже человека.

Статусная идентичность молодежи, как осознание молодежью своей социальной позиции, отражает особенности ее социального статуса, состоящего в предписанности, предопределенности и лишь формирующейся позиции индивидов, которые составляют молодежь. В социальном статусе молодых превалирует не приобретенная, а предписанная его составляющая. Но в молодежном возрасте индивиды имеют большие возможности приобретения различных значимых для социального статуса признаков (образовательных, профессиональных, экономических, властных, престижных и т. А.). Поэтому статусная идентичность молодежи является динамичной и перспективной, интенсивно развивающейся и, как правило, позитивно направленной. Но может взять верх и отрицательный полюс идентичности, когда молодой человек становится таким, каким не должен быть. 
Каждый человек в обществе обладает несколькими статусами и множеством социальных ролей. Их интеграция индивидуальна и зависит от целого комплекса особенных обстоятельств (Кон, 1999). Аостижение статусной идентичности предполагает выполнение человеком определенных социальных функций, следования моделям поведения, заданным его социальной позицией в системе общественных отношений. Осознание человеком своей тождественности ролевому набору, который соответствует достигнутым им статусам, и есть ролевая идентичность.

Присвоенная индивидом социальная роль, являясь деиндивидуализированным образцом поведения, персонифицирует сложившиеся общественные отношения в конкретных личностях. Многие роли (отец, мать, учитель, водитель и др.) можно определить как специфический социальный тип и связанное с ним типическое поведение. Ролевая идентичность позволяет закреплять это в личности. Социальные роли обусловливают важнейшие черты и свойства личности, и прежде всего тождественное, идентичное в индивидах. Субъективно для индивида ролевая идентичность выступает как его образ «Я». Я-концепция - система представлений о себе, конструируемая индивидом в процессе реализации множества социальных функций как совокупности ролей, называемой ролевым набором. Исполнитель роли способен субъективно отделяться от нее (Гоффман, 1973). Гоффман ввел термин «ролевая дистанция», подчеркивая различия между ожиданиями в отношении социальных ролей, исполнением роли и привязанностью индивида к своей роли. Ведь индивид - нечто большее, чем предписано ролью. Он вынужден дистанцироваться от нее и обращаться с ней по своему усмотрению.

Формирование идентичностей членов общества, как правило, институционализировано, связано с основными социальными институтами (семья, образование, политика, труд, экономика и др.) и ориентировано на их участие, соответствующую подаержку и требования. Разрушение или резкое изменение социальных институтов приводит к массовой утрате идентификации.

Так, кардинальные перемены в обществе и распад СССР, разрушение экономических структур в России в первой половине 1990-х годов ХХ в. привели к массовой дезориентации, утрате статусной идентичности представителями многих профессиональных групп, а ликвидация КПСС привела к утрате идентичности миллионов людей, для которых эта партия играла важнейшую роль в самоидентификации. Многие люди утратили свою статусно-ролевую идентичность и внутреннее чувство непрерывности и тождественности личности. Они переживали ряд негативных состояний, включая пессимизм, тревогу, чувства беспомощности и безнадежности (Антонова, 1996). Ранее достигнутая идентичность потеряла свою жизненность из-за расхождения прежних целей, ценностей, убеждений с требованиями изменившейся жизни. Такое состояние человек может преодолеть путем самостоятельного принятия решений относительно того, каким ему быть далее и стоит ли прилагать усилия по принятию новых ценностей, видов деятельности, образцов поведения.

Формирование идентичности является динамическим процессом кристаллизации представлений индивида о себе (Эриксон, 1996). Прежде всего, он осознает свое «Я», а также принадлежность к различным социальным образованиям, в которых протекает его жизнедеятельность. Но не всегда этот процесс имеет позитивный результат и отражает удовлетворенность человека своей идентичностью. Человек не всегда имеет возможности достичь желаемого статуса. Внезапное осознание неадекватности существующей идентичности вызывает критическое состояние индивида. Это кризис идентичности, который сопровождается резким изменением субъективного пережи- 
вания человеком своей индивидуальности в ее персональном или социальном значении (Ковалева, 2008). Кризис означает осознание индивидом необходимости иной идентичности. Он корректирует свои амбиции, ищет способы замещения и компенсации статусной идентичности. Как правило, общество или социальные группы выдвигают новые задачи и предлагают новые возможности для индивида.

Аит.: Антонова, Н. В. (1996) Проблема дичностной идентичности в интерпретации современного психоанализа, интеракционизма и когнитивной психологии // Вопросы психологии. №1. С. 131-143; Ковалева, А. И. (2008) Идентичности кризис // Социология молодежи. Энциклопедический словарь / отв. ред. Ю. А. Зубок, В. И. Чупров. М. : Academia. С. 145-146; Кон, И. С. (1999) Социологическая психология. М. : Московский психолого-социальный институт ; Воронеж : Издательство НПО «МОАЭК». 560 с.; Эриксон, Э. (1996) Идентичность: юность и кризис : пер с англ. М. : Прогресс. 343 с.; Goffman, E.(1973) Rollendistanz // Interaktion: Spafi am Spiel. Rollendistanz. Munchen. S. 101-116; Marcia, J. E. (1980) Identity in adolescence // Adelson J. (ed.) Handbook of adolescent psychology. N. Y. : John Wiley.

Аата поступления: 12.03.2018 2.

\section{STATUS AND ROLE IDENTITY \\ A. I. KOVALEVA \\ MOSCOW UNIVERSITY FOR THE HUMANITIES}

The paper considers the term "status and role identity", which defines the type of social identity that characterises the results of an individual's social identity process with reference to the statuses and roles that they acquired.

Keywords: status and role identity; identity; social status; social role; young people

\section{REFERENCES}

Antonova, N. V. (1996) Problema lichnostnoj identichnosti v interpretacii sovremennogo psihoanaliza, interakcionizma i kognitivnoj psihologii. Voprosy psibologii, no. 1, pp. 131-143. (In Russ.).

Kovaleva, A. I. (2008) Identichnosti krizis. In: Sociologiya molodezhi. Enciklopedicheskij slovar' / ed. by Yu. A. Zubok and V. I. Chuprov. Moscow, Academia. Pp. 145-146. (In Russ.).

Kon, I. S. (1999) Sociologicheskaya psibologiya. Moscow, Moskovskij psihologo-social'nyj institut; Voronezh, Izdatel'stvo NPO «MODEK». 560 p. (In Russ.).

Ehrikson, Eh. (1996) Identichnost': yunost' i krizis : transl. from Engl. Moscow, Progress. 343 p. (In Russ.).

Goffman, E. (1973) Rollendistanz. In: Interaktion: Spafi am Spiel. Rollendistanz. Munchen. Pp. 101-116.

Marcia, J. E. (1980) Identity in adolescence. In: Adelson J. (ed.) Handbook of adolescent psychology. N. Y. : John Wiley.

Submission date: 12.03 .2018$.

Ковалева Антонина Ивановна - доктор социологических наук, профессор, проректор по учебной работе, заведующий кафедрой социологии Московского гуманитарного университета, академик Международной академии наук (IAS). Адрес: 111395, Россия, г. Москва, ул. Юности, А. 5, корп. 1. Тел.: +7 (499) 374-60-21. Эл. адреc: aikovaleva@mail.ru

Kovaleva Antonina Ivanovna, Doctor of Sociology, Professor, Vice Rector for Education, Head, Department of Sociology, Moscow University for the Humanities; Full Member, International Academy of Science. Postal address: 5, Bldg. 1, Yunosti St., Moscow, Russian Federation, 111395. Tel.: +7 (499) 374-60-21.E-mail: aikovaleva@mail.ru 